\author{
Abstracta Iranica \\ Abstracta Iranica Revue bibliographique pour le domaine irano-aryen \\ Volume 40-41 | 2019 \\ Comptes rendus des publications de 2017-2018
}

\title{
Judith A Lerner. "Preliminary Remarks on an Achaemenid Seal with a Phrygian Inscription"
}

Astrid Nunn

\section{(2) OpenEdition}

\section{Journals}

Édition électronique

URL : http://journals.openedition.org/abstractairanica/49948

DOI : 10.4000/abstractairanica.49948

ISBN : 1961-960X

ISSN : 1961-960X

Éditeur :

CNRS (UMR 7528 Mondes iraniens et indiens), Éditions de l'IFRI

Référence électronique

Astrid Nunn, « Judith A Lerner. "Preliminary Remarks on an Achaemenid Seal with a Phrygian

Inscription" ", Abstracta Iranica [En ligne], Volume 40-41 | 2019, document 68, mis en ligne le 30

octobre 2019, consulté le 20 avril 2021. URL : http://journals.openedition.org/abstractairanica/49948

DOI : https://doi.org/10.4000/abstractairanica.49948

Ce document a été généré automatiquement le 20 avril 2021.

Tous droits réservés 


\title{
Judith A Lerner. "Preliminary Remarks on an Achaemenid Seal with a Phrygian Inscription"
}

\author{
Astrid Nunn
}

\section{RÉFÉRENCE}

Judith A Lerner. "Preliminary Remarks on an Achaemenid Seal with a Phrygian Inscription" in Friedhelm Pedde, Nathanael Shelley (eds.). Assyromania and More. In Memory of Samuel M. Paley, marru 4, Zaphon, Münster, 2018, p. 373-383

1 Le Buffalo Museum of Science conserve plus de 400 sceaux cylindres et cachets qui doivent bientôt être publiés. L'A. en a choisi un de l'époque achéménide pour honorer le défunt S. Paley. Il s'agit d'un cylindre en agate, dont la gravure représente un « héros » maîtrisant deux lions. Alors que l'image est grosso modo courante, certains détails le sont beaucoup moins: les lions sont tête-bêche, "une barre " terminée de chaque côté par un croissant lunaire et l'inscription, d'abord pensée être lydienne, maintenant acceptée comme étant phrygienne. En effet le possesseur du sceau portait le nom de Mane(s), courant en Phrygie et en Lydie. Plus exceptionnel est la position des lions que l'A. ne retrouve que sur des sceaux mycéniens, beaucoup plus anciens et d'une région lointaine. Le manque d'images parallèles, aussi bien dans la glyptique achéménide centrale que périphérique intrigue l'A. S'agit-il d'un sceau très provincial, ou bien reflète-il d'autres conventions visuelles de la Phrygie que nous ignorons? 


\section{AUTEURS}

\section{ASTRID NUNN}

Université de Munich 